\title{
Squamous cell carcinoma and precursor lesions of the oral cavity: epidemiology and aetiology
}

\author{
Newell W. Johnson, Prasanna Jayasekara \& A. A. Hemalatha K. Amarasinghe
}

People diagnosed with malignant neoplasms often feel afraid and alone. However, cancer is largely an avoidable disease, and studies have shown that more than two-thirds of cancer deaths may be prevented through lifestyle modification, early detection and effective treatment. The World Health Organization (WHO) estimates that nearly 12.7 million new cases and 7.6 million cancer deaths occurred worldwide in 2008 (27).

Oral cancers are malignant neoplasms that affect the structures or tissues of the mouth. They may be a primary lesion that originated in the mouth, a metastasis from a distant site, or an extension from an adjoining site. In quoting detailed epidemiological data, it is necessary to distinguish between these origins, and to ascertain which structures are included, e.g. the vermillion borders of the lips are sometimes included and sometimes not. Globally, 'oral cancer' is the eighth most common cause of cancer-related deaths, although many people are unaware of its existence (91). Of these oral cancers, more than $90 \%$ are squamous cell carcinomas arising in the mucous membranes of the mouth and oropharynx.

\section{Epidemiology of oral cancer}

\section{Incidence rates worldwide}

Cancer registries play a vital role in monitoring the incidence of cancers. However, the quality of the data available in such registries is far from ideal. Furthermore, many parts of the world produce no data at all, whereas in others (often among the most popu- lous), the data may come from localized atypical regions. Hospital-based cancer registries naturally gather biased information, i.e. only those cases that present to hospital; thus, in many developing countries, cases may not come to attention at all, either because of fear or the inability of poor people to access hospital services. Data may be even more unreliable because follow-up, even of treated cases, is impossible in many developing countries. Death certification is not always compulsory, and there is limited international standardization with regard to the categories for cause of death, nor consistency among of those signing death certificates.

Figure 1 shows the estimated incidence and mortality rates of the most common cancers by anatomic site in males and females. For both sexes combined, cancer of the mouth and pharynx [ICD-10 (C01-C14)] is placed ninth overall, behind breast, prostate, lung, colon/rectum, cervix uteri, stomach, liver and corpus uteri, in that order. In the published data for 2008, oral and pharyngeal sites were the eighth most common neoplasms within the European Union (28). However, the mouth and pharynx are the sixth most common site for malignant disease among men in developing countries and the eighth most common site among women. According to the GLOBOCAN 2008 database produced by the International Agency for Research on Cancer, there were some 399,546 new cases worldwide of oral cancer (C00-C08) and other pharyneal cancers (C09-C10, C12-C14) (27). Estimated age-standardized rates for the incidence and mortality of cancer of the lip and mouth (C00-08) and the pharynx (C09-C10, C12-C14), excluding the salivary gland, 2008, by sex and geographic area, are 

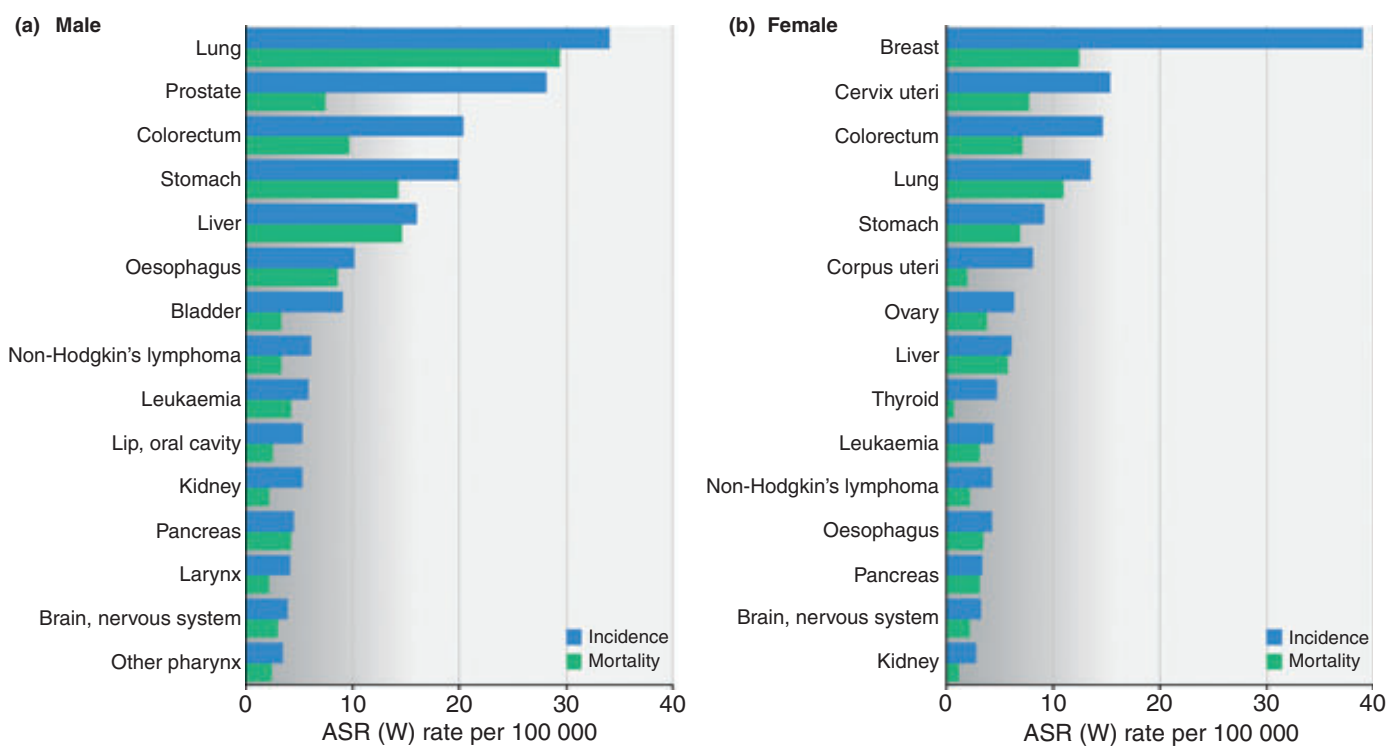

Fig. 1. Estimated global incidence and mortality rates (standardized to a world population age distribution) of the 14 most common cancers in men (left) and the 15 most common cancers in women (right). Modified from (27). Rates are standardised to the age structure of the total world population (ASR(W))

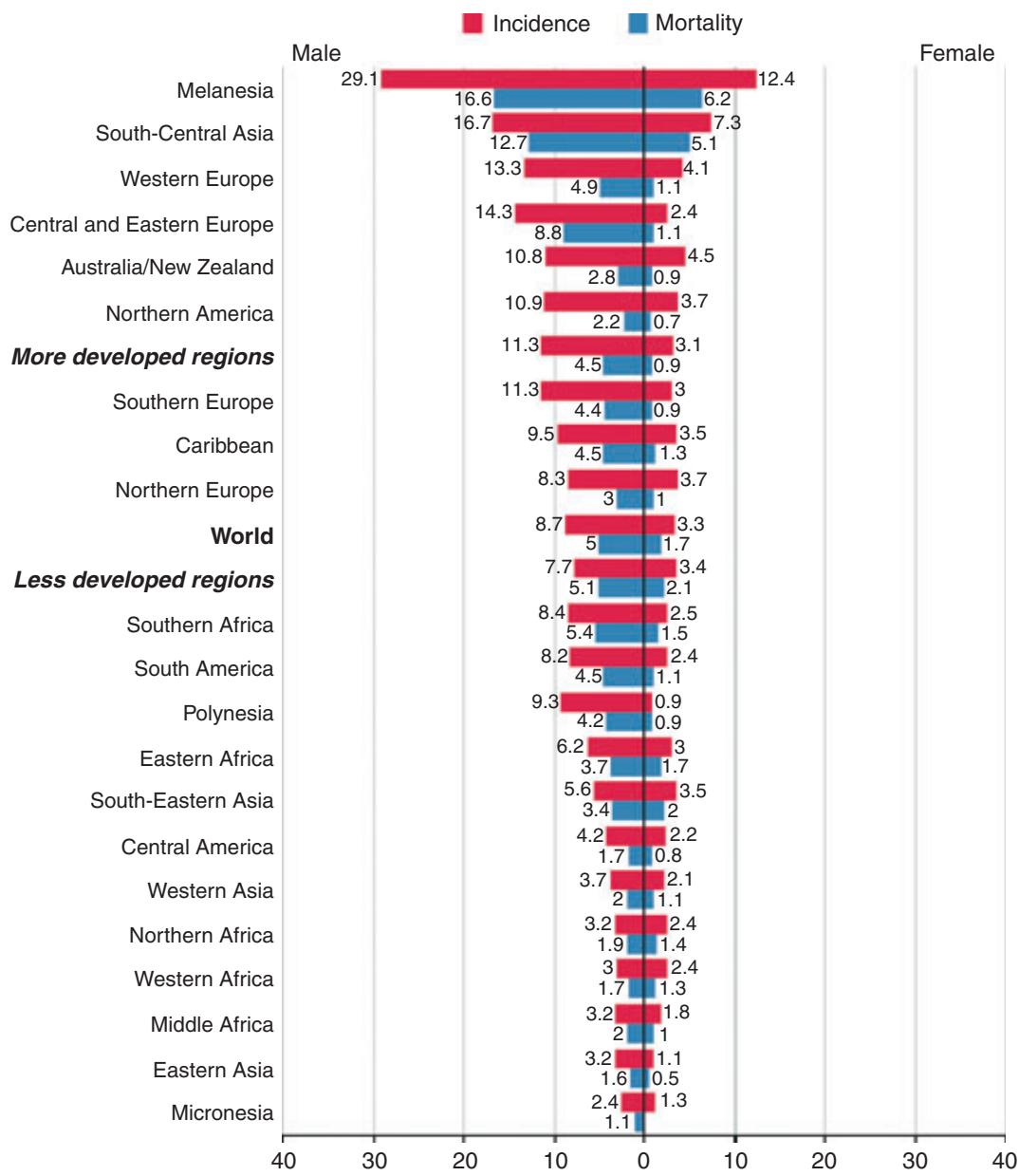

Fig. 2. Estimated age-standardized rates for the incidence and mortality of cancers of the lip and mouth (C00-C08) and pharynx (C09-C10, C12-C14), excluding the salivary gland, by sex and WHO geographic area. Values are ASR (W) per 100000 population (all age groups). Modified from (27).

shown in Fig. 2 (27). The rates range from $<1 / 100,000$ per annum (for female subjects in parts of Africa, Eastern Asia and some Pacific Island nations) to a high of 29.1/100,000 per annum (males in Melanesia). These rates illustrate the marked global variability in oral cancer incidence, (136) and 


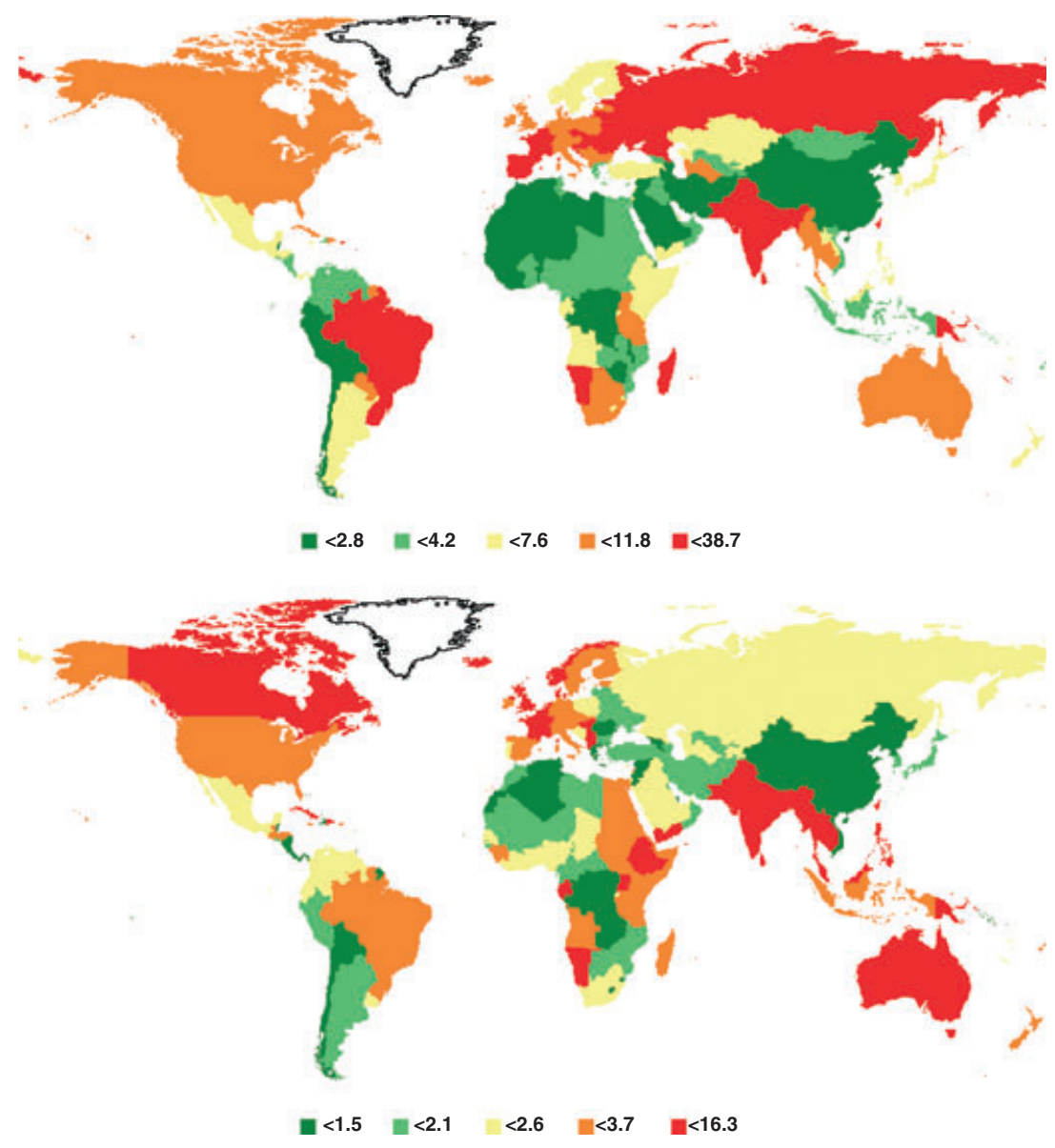

Fig. 3. Estimated age-standardized oral and pharyngeal cancer incidence rates per 100000 population throughout the world, showing marked geographical variation in incidence. Care is needed in interpretation because some large groupings disguise marked regional variation. The top part of the figure shows the data for males; the lower part shows the data for females. Modified from (27). are illustrated in Fig. 3 (27). The highest crude rates in the world are found in Melanesia, Hungary, France, Sri Lanka and Croatia (27).There are marked differences between countries in the same geographical region $(77,78)$.

The extremely high rates in the relatively small population of Melanesia are thought to relate to areca nut (betel) chewing and smoking habits. It has been apparent for decades that there is a very high incidence of oral cancer in southern Asia and of oral cavity plus nasopharyngeal cancer in South-East Asia. In India, Bangladesh, Pakistan and Sri Lanka, the oral cavity is the most common site for cancer, and accounts for approximately one-third of all cancers (104). Even within the sub-continent, there are striking differences in incidence rates. More than 180,000 cases of oral cancer occur every year in South and South-East Asia, with poor prospect of survival: approximately $90 \%$ of these cases are attributable to smoking and chewing habits (142). However, overall rates in India are showing a decreasing trend in successive birth cohorts: decreasing trends were observed for mouth (ICD-10 C03-C06) and tongue (C01-C02) cancers among females and for tongue cancers among males between 1982 and 2000 (107), and these trends are likely to continue as the Indian economy grows and habits change from betel quid use to use of other forms of tobacco, especially smoking. On the other hand, there is growing concern that supply of commercial areca nut and tobacco products for chewing will contribute to future increases in the incidence of oral sub-mucous fibrosis and subsequent oral cancer (38).

Data in Japan show a dramatic increase in oral and pharyngeal cancer incidence (ICD-10 C01-C14) for both sexes: a 4.4-fold increase for males and 3.8-fold increase for females were recorded between 1965 and 1999 in the Osaka Cancer Registry's database (54). The estimates of oral cancer for the year 2008 in the USA indicate that there were 35,310 new cases and 7,590 deaths (54). This represents $1.34 \%$ of all deaths due to cancer in that country. In the USA, The incidence rates for cancers of the oral cavity and pharynx were stable or decreased for men and women in most age groups during the period 1973-2003. Unfortunately, there is an upward trend for both males and females in Australia and among the non-Maori population in New Zealand. Lip cancer in fair-skinned populations, largely due to ultraviolet light and especially near the equator, is a growing problem (76). In Europe, 
Hungary has the highest incidence and mortality of oral and pharyngeal cancer for both sexes (28). Between 1984 and 1994, the Hungarian mortality rates for oral cancers increased by $84 \%$ and $72 \%$ in males and females, respectively. The mortality rates among Italian and French males peaked in the 1980s and decreased after 1990 (126). However, continuing upward trends have been recorded for Belgium, Denmark, Greece, Portugal and Scotland (11).

\section{Age distribution}

Oral cancer is usually a disease that occurs in males after the 5th decade of life. The mean age at presentation is in the fifth and early sixth decades in Asian populations, compared with the seventh and eighth decades in the North American population $(14,23,53,61,62,118)$. Statistics in the USA for 20032007 show that the median age at diagnosis for cancer of the oral cavity and pharynx was 62 years (2).

Studies have suggested that $4-6 \%$ of oral cancers now occur at ages younger than 40 years (64). An alarming increase in incidence of oral cancers among younger people has been reported from many parts of the world $(5,69,108,138)$, a trend that appears to be continuing. There was a significant increase in cancers of the tongue and tonsils among 20-40-yearolds in the USA between 1973 and 2001 (116). In Germany, Czechoslovakia and Hungary, there has been an almost 10-fold increase within one generation in mortality from oral cancer in men aged 35-44 (113). Robinson \& Macfarlane showed a dramatic increase in incidence for younger males in Scotland from the 1980s to the 1990s (103), and the increase has continued in young adults in much of the UK. UK cancer registries currently show that $6 \%$ of all oral cancers occur in people under the age of 45 years (138). In the high-prevalence areas of the world, many patients are $<40$ years old, partly owing to heavy abuse of various forms of tobacco, although this is not the case in parts of India (25).

A study performed in southern England concluded that a substantial proportion of cases of oral cancer in younger people occurred in the absence of, or after a relatively short duration of exposure to, traditional risk factors (65). This suggests that factors other than tobacco and alcohol are implicated in the development of oral cancer in a significant minority of cases. Diets poor in fresh fruits and vegetables were identified as conferring significant risk in this population. It has also been suggested that greater attention should be paid to family history and a possible hereditary predisposition in younger patients with oral cancer in younger patients with oral cancer (43). An increase in incidence of oropharyngeal cancers in the USA, especially of the tongue base and tonsils, has occurred in individuals aged 40-45 years: these tumours are frequently positive for high-risk types of human papillomavirus, especially type 16 (70).

\section{Sex distribution}

Worldwide, the incidence of head and neck cancers is higher for males than females. According to the International Agency for Research on Cancer (27), the mean global age-specific incidence of mouth and pharyngeal cancer excluding the nasopharynx for males in 2008 was $8.7 / 100,000$ population, compared to 3.3 for females. This may be because of the greater indulgence by men in the most important risk factors, such as heavy alcohol and tobacco consumption for intra-oral cancer and sunlight for lip cancer in those who work outdoors. However, oral cancer in females is increasing in some parts of the world. For example, a meta-analysis from Buenos Aires showed the male/female ratio to be 1.24 :1 for the period 19922000 compared to 7.1:1 for the period 1950-1970, due to an alarming increase in the number of female cases (12). The incidence of tongue and other intra-oral cancers for women is greater than or equal to that for men in high-incidence areas such as some regions of India, where betel quid/areca nut chewing (and sometimes smoking) are common among women.

Within Europe, the incidence of oral cavity and pharyngeal cancers $(\mathrm{C} 00-\mathrm{C} 14$ in the most recent period, i.e. within the GLOBOCAN 2008 database) is highest among males in Hungary (46.1/100,000 per annum), and lowest among females in Cyprus and Greece (1.5 and 2.0, respectively). Between 1990 and 1999, the UK incidence rates for oral cancers increased in males of all ages from 6.5 to $8.3 / 100,000$ (an increase of $18 \%$ ) and in females from 2.6 to $3.6 / 100,000$ (an increase of $30 \%$ ) (16). The male to female ratio in UK in 2008 was 2.1:1 (28).

In the USA, the death rate due to cancer of the oral cavity and pharynx per 100,000 population in 2005 was 3.9 for males and 1.4 for females, down from 6.9 and 2.3, respectively, in 1975. This substantial improvement is not reflected in most of the rest of the world (2). Apart from the typical risk factors, it has been suggested that oestrogen deficiency may influence susceptibility to oral cancer in women: a significantly younger mean age at menopause and higher rates of hysterectomy may influence the higher rates of oral cancer seen among younger females in the West (122). 


\section{Ethnic variations}

Variations by ethnicity may be due to social and cultural practices, as well as the influence of dietary and genetic factors. Variations in outcome are also contributed to by differences in access to healthcare. Where cultural practices represent risk factors, their continuation by immigrants from high-incidence regions to other parts of the world results in comparatively high rates in immigrant communities. This can also influence the sub-sites most commonly affected (63). The highest age-adjusted oral cancer rates in USA are found among non-Hispanic black men $(4.86 / 100,000)$ followed by non-Hispanic black women $(4.71 / 100,000)$, then Asian and Hispanic populations, with the lowest incidence rates in white (Caucasian) ethnic groups. Tongue cancer was the commonest type of oral cancer among every ethnicity. Asians were more likely to develop malignancies in the buccal mucosa, a reflection of continuing areca- and tobacco-chewing habits. Another study showed that American Indians and Alaska Natives had significantly lower incidence rates overall than non-Hispanic whites (102). Several studies from the USA have shown that black patients with oral cancer have poorer overall and disease-specific survival than whites, mainly because of their comparatively poor access to health care (36). This is especially concerning because the incidence of oral plus pharyngeal cancer for black men in the USA is so high, and it is the sixth most common site for malignant disease amongst this group (121).

The age-adjusted incidence of oral and pharyngeal cancers is higher for South Asians than non-South Asians resident in England, particularly among females (74). Interestingly, south Asian males have significantly better survival than their non-south Asian peers in the south-east of England, possibly a reflection of the slower progress of tobacco/areca nut-induced lesions (74).

\section{Mortality rates and trends}

Global differences in mortality from oral (C00-C08) and other pharyneal cancers (C09-C10, C12-C14) in 2008 are illustrated in Fig. 4. According to GLOBOCAN 2008, the highest mortality from oral cancer is found in Melanesia (16.6/100 000 in men and 6.2/100 000 in women) (27). There was a steady increase in oral cancer mortality in men from the 1950s to the late

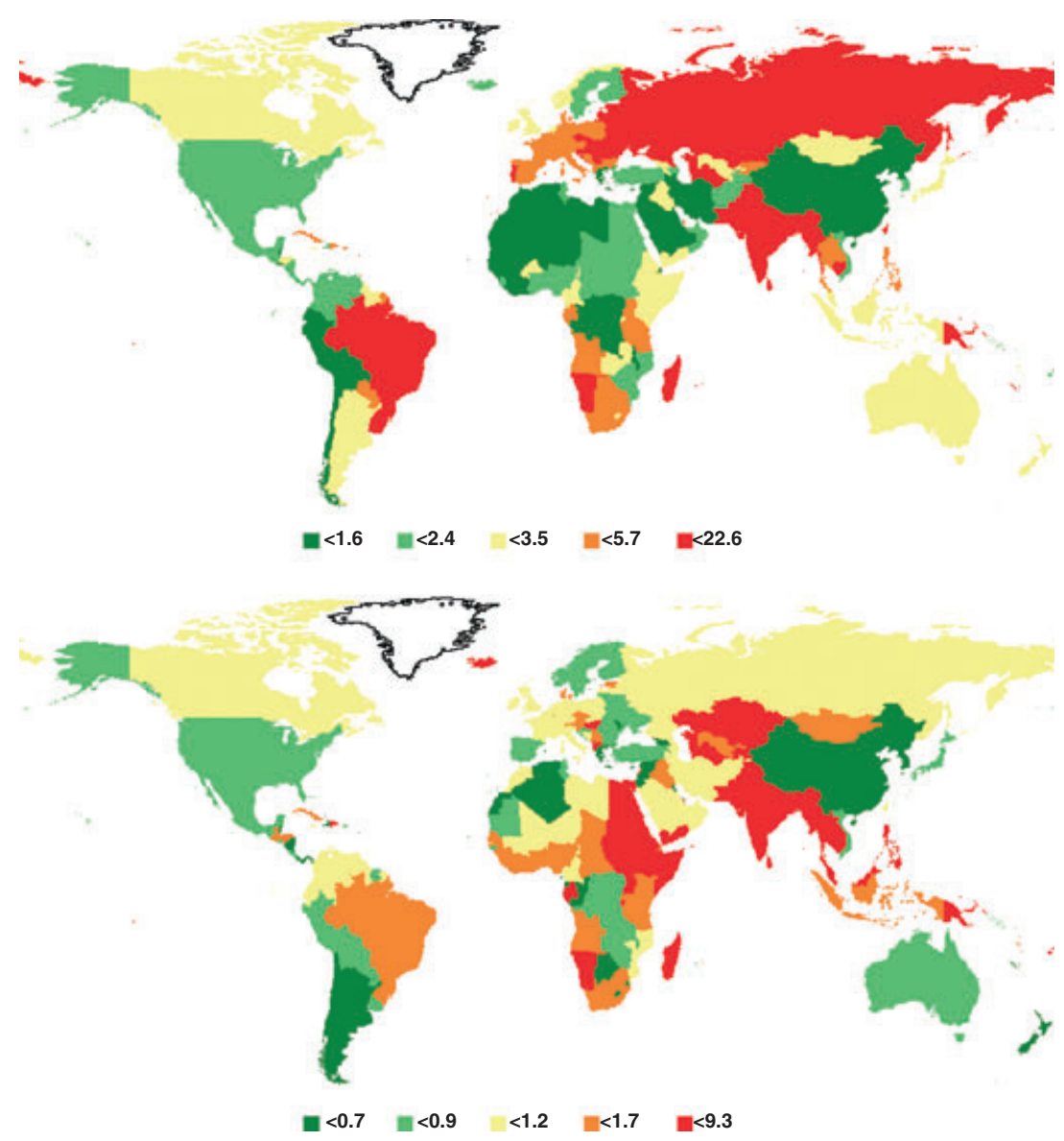

Fig. 4. Estimated age-standardized oral cancer and pharyngeal mortality rates per 100000 population. The top part of the figure shows the data for males; the lower part shows the data for females. Modified from (27). 
1980s in most Western European countries (57), but this trend has since declined, e.g. in France, which had very high rates in the past. In most countries in central and Eastern Europe, for example Hungary, Slovakia, Slovenia and the Russian Federation, oral cancer mortality in men reached exceedingly high rates up to the 1990s. Hungary, Ukraine, Estonia and Bulgaria showed more than $100 \%$ increases in mortality rates for men during the 20 -year period from 1980-2000. There are now the beginnings of a reversal.

Even though the rates of oral cancer are comparatively low among women, there is a steady increase in some countries in Europe (notably Hungary, Belgium, Denmark and Slovakia). Hungary also showed a $98 \%$ increase in mortality rates for women (Available at http://www-dep.iarc.fr/WHOdb/WHOdb. $\mathrm{htm})$. These disturbing trends are thought to relate to high levels of drinking and smoking in these societies, together with poor diet in lower socio-economic groups. Trends of age-standardized (world population) mortality rates from oral or pharyngeal cancer within selected countries during the period from 1980 to the present are shown in Fig. 5A,B.

The Surveillance Epidemiology \& End Results (SEER) programme in the USA reported an overall decrease in the mortality from oral and pharyngeal cancer between 1998 and 2007 of 1.6\% per annum. Table 1 shows a decrease in all mortality rates for oral and pharyngeal cancer in the USA between 1998 and 2007. The decrease is considerable among both Hispanic and black women (annual percentage changes of $-1.6 \%$ and $-3.7 \%$, respectively). Furthermore, the SEER data show better five-year survival rates for white men $(62.2 \%)$ and for black men $(37.5 \%)$ diagnosed during the period 1999-2006, than for those diagnosed during the period 1974-1976 (when rates for whites and blacks were $55 \%$ and $36.3 \%$, respectively) (79). The five-year survival rates in the SEER registries range from a low of $53.3 \%$ in $1975-1977$ to a high of $62.7 \%$ in 1999-2006 (2). These striking differences may be explained by a number of factors, including socio-economic condition, age, stage at diagnosis, continued presence or absence of environmental risk factors, and access to hospital services. African-American patients have consistently poorer survival outcomes (75).

A study in Mumbai, India, (88) indicated a decreasing trend in oral cancer incidence among Indian men, which may be due to a decrease in the use of betel quid/pan and associated oral smokeless tobacco over this period (123). However, there continues to be a high prevalence of smokeless tobacco use among young adult men and women, especially in the form of pan parag/gutka-type products, and cigarette smoking is increasing. Overall, therefore, upper aero-digestive tract cancers may not decrease.

Population-based survival rates around the world show little evidence of improvement over recent decades, despite vast improvements in the field of medicine. Cure rates and survival rates have improved with advances in surgical and other techniques in highly specialized, high-volume treatment institutions. Regrettably, such highly expert management is not yet uniformly available, and it will be many more decades before these results are reflected in population trends.

\section{Oral potentially malignant disorders}

The term 'oral potentially malignant disorders' (OPMD) was recommended by an international working group convened by the WHO Collaborating Centre for Oral Cancer and Pre-Cancer in London in 2005 (137). It indicates that not all disorders thus described will transform to invasive cancer - at least not within the lifespan of the affected individual. Leukoplakia, erythroplakia, oral sub-mucous fibrosis, lichen planus, palatal lesions in reverse smokers, actinic keratosis, discoid lupus erythematosus, dyskeratosis congenita and epidermolysis bullosa are fall into the broad definition of 'oral potentially malignant disorders' $(132,137)$.

\section{Global prevalence}

Estimates of the global prevalence of oral potentially malignant disorders range from $1-5 \%$ (85), although much higher prevalences are reported from South East Asia, usually with a male preponderance, e.g. Sri Lanka (11.3\%) (3), Taiwan (12.7\%) (15), and some Pacific countries (Papua New Guinea 11.7\%) (128). Wide geographical variations across countries and regions are mainly due to differences in sociodemographic characteristics, the type and pattern of tobacco use and clinical definitions of disease (Table 2). In Western countries, the overall prevalence is low and a decrease over time is observed.

Petti (93) performed a meta-analysis of 23 primary studies on oral leukoplakia published between 1986 and 2002 . He calculated the point prevalence to be $1.49 \%$ (95\% confidence interval $1.42-1.56 \%$ ) or $2.6 \%$ (1.72-2.74\%) using a random effects model. Leukoplakia was significantly more prevalent among males 

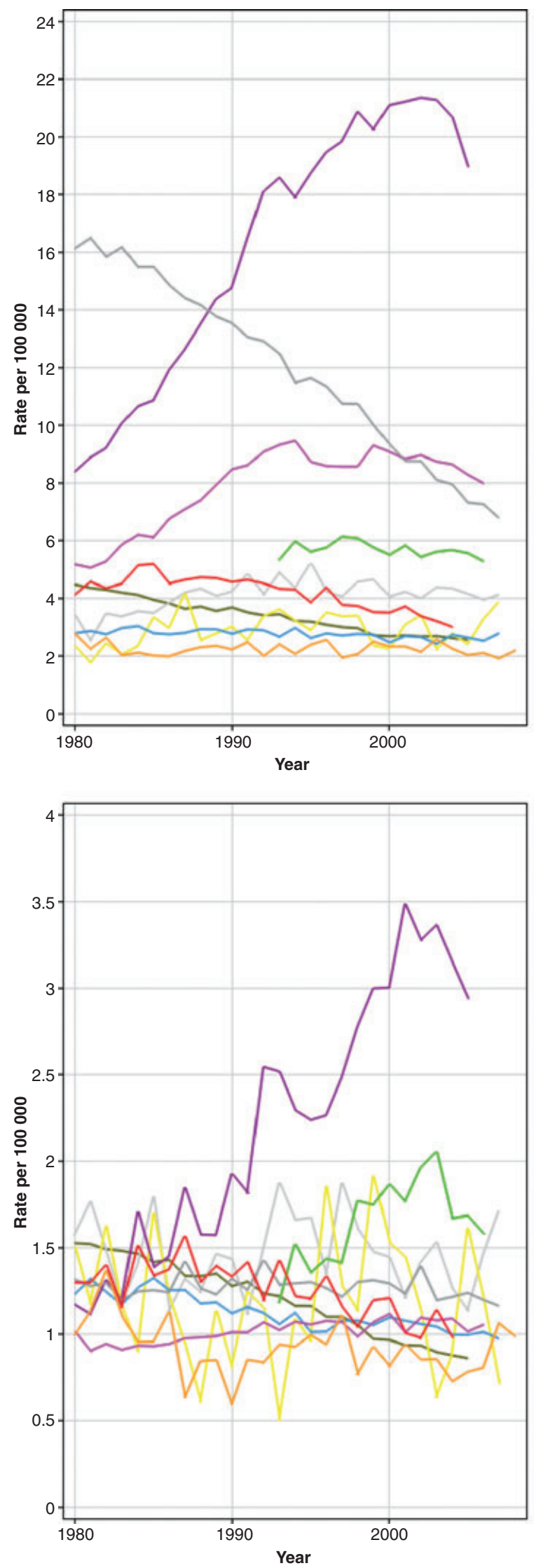

Australia

China: selected rural areas

China: selected urban areas

Finland

France

Hungary

Russian Federation

South Africa

UK, England and Wales

UK, Northern Ireland

UK, Scotland

United States of America
Australia

China: selected rural areas

China: selected urban areas

Finland

France

Hungary

Russian Federation

South Africa

UK, England and Wales

UK, Northern Ireland

UK, Scotland

United States of America
Fig. 5. Trends in age-standardized (world standard population) mortality rates from oral plus pharyngeal cancer per 100000 per annum for selected countries, from 1980 to present. Top, males; bottom, females (59). Although only approximately a tenth of the male rate, the rate in Hungarian females remains a challenge. (Available at http://www-dep.iarc.fr/ WHOdb/WHOdb.htm). 
Table 1. Mortality rates and trends by race/ethnicity and sex for oral and pharyngeal cancer in the USA between 1975 and $2007(2)$

\begin{tabular}{|c|c|c|c|c|c|c|}
\hline \multirow[t]{2}{*}{ Race / ethnicity } & \multicolumn{3}{|c|}{ Rate $2003-2007 / 100,000$} & \multicolumn{3}{|c|}{$\begin{array}{c}\text { Trend } 1998-2007^{\dagger} \\
\text { AAPC }(\%)\end{array}$} \\
\hline & Total & Males & Females & Total & Males & Females \\
\hline All races & 2.5 & 3.9 & 1.4 & $-1.6^{*}$ & $-1.6^{*}$ & $-2.3^{*}$ \\
\hline White Hispanic & 1.6 & 2.5 & 0.8 & $-3.0^{*}$ & $-3.8^{*}$ & $-1.6^{*}$ \\
\hline $\begin{array}{l}\text { White } \\
\text { non-Hispanic }\end{array}$ & 2.5 & 3.8 & 1.5 & $-1.1^{*}$ & $-0.9 *$ & $-1.9^{*}$ \\
\hline Black & 3.6 & 6.3 & 1.5 & $-3.7^{*}$ & $-3.7^{*}$ & $-3.7^{*}$ \\
\hline $\begin{array}{l}\text { Asian / Pacific } \\
\text { Islander }\end{array}$ & 2.1 & 3.1 & 1.2 & $-2.6^{*}$ & $-2.8^{*}$ & $-1.8^{*}$ \\
\hline $\begin{array}{l}\text { American } \\
\text { Indian / Alaska } \\
\text { Native }\end{array}$ & 1.9 & 2.9 & 1.2 & $-1.7^{*}$ & $-2.4^{*}$ & \\
\hline
\end{tabular}

The SEER programme covers registries in 17 areas [San Francisco (SF), Connecticut, Detroit, Hawaii, Iowa, New Mexico, Seattle, Utah, Atlanta, San Jose-Monterey (SJM), Los Angeles (LA), the Alaska Native Registry, rural Georgia, California excluding SF/SJM / LA, Kentucky, Louisiana and New Jersey). California excluding SF / SJM / LA, Kentucky, Louisiana and New Jersey contributed cases for diagnosis years 2000-2006. The remaining 13 SEER areas contributed cases for the entire period (1999-2006). Results are based on follow-up of patients into 2007.

AAPC, average annual percentage change.

*The AAPC is significantly different from zero $(P<0.05)$.

The 1998-2007 mortality AAPCs are based on a Joinpoint analysis using years of death 1992-2007.

(prevalence ratio 3.22). Using these data, he calculated that the crude annual oral cancer incidence rate attributable to leukoplakia is between 6.2 and $29.1 / 100,000$, suggesting that the global number of oral cancer cases may be under-reported.

\section{Age and gender distribution}

The age and gender distribution of oral potentially malignant disorders varies considerably, mainly dependent on lifestyle and on geographical location and ethnicity. In the developed world, leukoplakia is usually found between the fourth and seventh decades of life, but in the developing world it is found some 5-10 years earlier (86). Females are less commonly affected, largely reflecting greater use of relevant habits in men.

\section{Malignant transformation}

The risk of malignant transformation varies from site to site within the mouth, from population to population, and from study to study $(95,100,119)$. A classic study of over 30,000 Indian villagers, performed in the 1970s with follow-up over 7 years, showed transformation rates between 10 and 24/100,000 per year (95). Another classic study from the early 1980s, a hospital-based study in Californian patients with oral leukoplakia, with a mean follow-up period of 7.2 years, revealed a malignant transformation rate of
$17.5 \%$ (119). Not surprisingly, rates for hospital-based studies are consistently higher than for communitybased studies because of sampling bias.

Petti (93) estimated a mean global prevalence of $2.6 \%$ for leukoplakia, and a mean global transformation rate of $1.36 \%$ per year $(95 \%$ confidence interval 0.69-2.03). These prevalence and transformation figures suggest an actual incidence of oral squamous cell carcinoma higher than that currently reported, possibly due to under-reporting of cases of oral cancer in the developing world.

\section{Aetiology of oral cancer and oral potentially malignant disorders}

The majority of oral squamous cell carcinomas are related to tobacco in various forms, areca nut/betel quid chewing, heavy alcohol drinking and dietary micronutrient deficiency. In the developing world, use of tobacco and areca nut, either alone or in combination, accounts for the vast majority of oral cancers and oral potentially malignant disorders (3). The WHO has classified areca nut, a common component of many different chewing habits, as carcinogenic to humans (51). UV radiation is relevant to lip cancer, and there is now unequivocal evidence for a role of 'high-risk' genotypes of the human papilloma virus family, especially for tonsillar and other oro-pharyngeal sites. 
Table 2. Summary of the reported prevalence of oral potentially malignant disorders (OPMD)

\begin{tabular}{|c|c|c|c|c|c|c|c|}
\hline References & Country (year) & $\begin{array}{l}\text { Sampling } \\
\text { method }\end{array}$ & $\begin{array}{c}\text { Female } / \text { male } \\
\text { ratio }\end{array}$ & $\begin{array}{l}\text { Age group } \\
\text { (years) }\end{array}$ & Disease entity & $\begin{array}{l}\text { Definition } \\
\text { used }\end{array}$ & $\begin{array}{c}\text { Prevalence } \\
(\%)\end{array}$ \\
\hline $\begin{array}{l}\text { Thomas et al. } \\
\text { (128) }\end{array}$ & $\begin{array}{c}\text { Papua New } \\
\text { Guinea (2008) }\end{array}$ & Random & $0.8 / 1.0$ & $\geq 18$ & Leukoplakia & Axell 1984 & 11.7 \\
\hline $\begin{array}{l}\text { Amarasinghe } \\
\text { et al. (3) }\end{array}$ & $\begin{array}{l}\text { Sri Lanka } \\
\text { (2008) }\end{array}$ & MSSC & $0.6 / 1.0$ & $\geq 30$ & $\begin{array}{l}\text { OPMD as de- } \\
\text { fined above }\end{array}$ & WHO 1994 & $\begin{array}{l}11.3 \text { (weighted } \\
\text { for gender and } \\
\text { geographical } \\
\text { location) }\end{array}$ \\
\hline $\begin{array}{l}\text { Chung et al. } \\
\text { (15) }\end{array}$ & Taiwan (2005) & Random & $0.9 / 1.0$ & $\geq 15$ & $\begin{array}{c}\text { OPMD } \\
\text { Leukoplakia } \\
\text { Erythroplakia } \\
\text { Lichen planus } \\
\text { OSF }\end{array}$ & Not given & $\begin{array}{c}12.7 \\
7.4 \\
1.9 \\
2.9 \\
1.6\end{array}$ \\
\hline $\begin{array}{l}\text { Scheifele } \\
\text { et al. (109) }\end{array}$ & USA (2003) & MSSC & $0.9 / 1.0$ & $\geq 20$ & Leukoplakia & $\begin{array}{l}\text { Kramer } 1978 \\
\text { Kramer } 1980\end{array}$ & $0.5-0.3$ \\
\hline $\begin{array}{l}\text { Ministry of } \\
\text { Health of Sri } \\
\text { Lanka (73) }\end{array}$ & $\begin{array}{l}\text { Sri Lanka } \\
\text { (2003) }\end{array}$ & MSSC & - & $\begin{array}{l}\text { 35-44 and 65- } \\
74\end{array}$ & $\begin{array}{c}\text { OPMD } \\
\text { Leukoplakia } \\
\text { and erythopla- } \\
\text { kia } \\
\text { OSF }\end{array}$ & WHO 1994 & $\begin{array}{l}4.1 \\
2.6 \\
0.4\end{array}$ \\
\hline $\begin{array}{l}\text { Garcia-Polo } \\
\text { Vallejo et al. } \\
(34)\end{array}$ & Spain (2002) & $\begin{array}{l}\text { Stratified, ran- } \\
\text { dom }\end{array}$ & $0.8 / 1.0$ & $\geq 30$ & Leukoplakia & $\begin{array}{c}\text { WHO } 1978 \\
\text { Axell et al. } 1984\end{array}$ & 1.6 \\
\hline $\begin{array}{l}\text { Reichart et al. } \\
(101)\end{array}$ & $\begin{array}{l}\text { Germany } \\
(2000)\end{array}$ & $\begin{array}{l}\text { Stratified, ran- } \\
\text { dom }\end{array}$ & $\begin{array}{l}1.0 / 1.0 \\
0.7 / 1.0\end{array}$ & $\begin{array}{c}35-44 \text { and } \\
65-74\end{array}$ & $\begin{array}{l}\text { Leukoplakia } \\
\text { Leukoplakia }\end{array}$ & $\begin{array}{c}\text { Axell } 1976 \\
\text { Zain } 1995 \\
\text { WHO-ICD-DA }\end{array}$ & $\begin{array}{l}1.6 \\
1.0\end{array}$ \\
\hline $\begin{array}{l}\text { Nagao et al. } \\
(80)\end{array}$ & Japan (2000) & All invited & $0.4 / 1.0$ & $\begin{array}{c}\text { Male }>40, \\
\text { female }>20\end{array}$ & $\begin{array}{c}\text { Leukoplakia } \\
\text { Lichen planus }\end{array}$ & WHO 1980 & $\begin{array}{l}0.19 \\
0.21\end{array}$ \\
\hline $\begin{array}{l}\text { Zain et al. } \\
\text { (147) }\end{array}$ & $\begin{array}{c}\text { Malaysia } \\
\text { (1997) }\end{array}$ & $\begin{array}{l}\text { Stratified, ran- } \\
\text { dom }\end{array}$ & $0.7 / 1.0$ & $\geq 25$ & $\begin{array}{c}\text { Leukoplakia } \\
\text { Erythroplakia } \\
\text { OSF } \\
\text { Lichen planus }\end{array}$ & $\begin{array}{c}\text { WHO } 1978 \\
\text { Axell et al. } 1984\end{array}$ & $\begin{array}{l}0.96 \\
0.01 \\
0.06 \\
0.38\end{array}$ \\
\hline $\begin{array}{l}\text { Schepman } \\
\text { et al. (110) }\end{array}$ & $\begin{array}{l}\text { The Nether- } \\
\text { lands (1996) }\end{array}$ & Waiting room & $0.9 / 1.0$ & $13-93$ & Leukoplakia & $\begin{array}{c}\text { Axell et al. } 1984 \\
\text { Axell } 1996 \\
\text { Schepman } \\
1995\end{array}$ & 0.6 \\
\hline $\begin{array}{l}\text { Banoczy } \\
\text { et al. (10) }\end{array}$ & Hungary (1991) & Random & $0.7 / 1.0$ & All age groups & $\begin{array}{l}\text { Leukoplakia } \\
\text { Lichen planus }\end{array}$ & Axell 1984 & $\begin{array}{l}1.3 \\
0.1\end{array}$ \\
\hline $\begin{array}{l}\text { Ikeda et al. } \\
(48)\end{array}$ & Japan (1991) & $\begin{array}{l}\text { Factory work- } \\
\text { ers }\end{array}$ & $0.5 / 1.0$ & $18-63$ & Leukoplakia & Axell 1984 & 2.5 \\
\hline $\begin{array}{l}\text { Axell et al. } \\
(8)\end{array}$ & $\begin{array}{l}\text { Sweden } \\
\text { (1987) }\end{array}$ & $\begin{array}{l}\text { Stratified, ran- } \\
\text { dom }\end{array}$ & Not found & $\geq 15$ & Lichen planus & Axell 1976 & 1.9 \\
\hline $\begin{array}{l}\text { Axell et al. } \\
\text { (7) }\end{array}$ & Sweden (1987) & $\begin{array}{l}\text { All invited resi- } \\
\text { dents }\end{array}$ & $0.9 / 1.0$ & $\geq 15$ & Leukoplakia & Axell 1976 & 3.6 \\
\hline
\end{tabular}

MSSC, multi-stage stratified cluster; OSF, oral submancous fibrosis.

\section{Betel quid}

A betel quid generally contains betel leaf, areca nut and slaked lime, and may contain tobacco. Other substances, particularly spices, including cardamom, saffron, cloves, aniseed, turmeric, mustard or sweet- eners, are added according to local preference (51). Betel quid with or without tobacco is considered carcinogenic to humans, with a risk of developing oral cancer and oral potentially malignant disorders $(51,114)$. Several studies have quantified the risk in terms of the odds ratio in different regions and 
Table 3. Meta-analysis of lifestyle factors and oral and pharyngeal cancers / oral potentially malignant disorders (OPMD)

\begin{tabular}{|c|c|c|c|c|c|}
\hline Publication & Lifestyle factor & $\begin{array}{l}\text { Oral cancer or } \\
\text { OPMD site }\end{array}$ & \multicolumn{2}{|c|}{$\begin{array}{l}\text { Number of studies } \\
\text { Case/ cohort control }\end{array}$} & $\begin{array}{c}\text { Odds ratio }(95 \% \\
\text { confidence interval) }\end{array}$ \\
\hline Gandini et al. (31) & Tobacco smoking & $\begin{array}{l}\text { Cancer of the } \\
\text { oral cavity } \\
\text { Cancer of the } \\
\text { pharynx }\end{array}$ & $\begin{array}{l}12 \\
8\end{array}$ & & $\begin{array}{l}3.43(2.37-4.94) \\
6.76(2.96-15.98)\end{array}$ \\
\hline $\begin{array}{l}\text { Tramacere et al. } \\
\text { (129) }\end{array}$ & $\begin{array}{c}\text { Alcohol } \\
\leq 1 \text { drink / day } \\
\geq 4 \text { drinks / day }\end{array}$ & $\begin{array}{c}\text { Oral and pharyngeal } \\
\text { cancer }\end{array}$ & $\begin{array}{l}19 \\
29\end{array}$ & $\begin{array}{l}1 \\
2\end{array}$ & $\begin{array}{l}1.21(1.10-1.33) \\
5.24(4.36-6.30)\end{array}$ \\
\hline $\begin{array}{l}\text { Tramacere et al. } \\
\text { (129) }\end{array}$ & $\begin{array}{l}\text { Alcohol } \\
\text { From 10-125 g } \\
\text { ethanol/day }\end{array}$ & $\begin{array}{c}\text { Oral and pharyngeal } \\
\text { cancer }\end{array}$ & 43 & 2 & $\begin{array}{c}\text { Odds ratios range } \\
\text { from } 1.29 \\
(1.25-1.32) \text { to } 13.02 \\
(9.87-17.18)\end{array}$ \\
\hline Turati et al. (131) & $\begin{array}{c}\text { Alcohol } \\
\text { Heavy drinker }(\geq 4 \\
\text { drinks / day equal to } \\
\text { more than } 50 \mathrm{ml} \text { or } \\
30 \mathrm{~g})\end{array}$ & $\begin{array}{l}\text { Oral cavity cancer } \\
\text { Pharyngeal cancer } \\
\text { Tongue cancer } \\
\text { Oropharyngeal } \\
\text { cancer } \\
\text { Hypopharyngeal } \\
\text { cancer }\end{array}$ & $\begin{array}{c}16 \\
17 \\
5 \\
4 \\
\\
4\end{array}$ & $\begin{array}{l}1 \\
- \\
- \\
-\end{array}$ & $\begin{array}{c}4.64(3.78-5.7) \\
6.62(4.72-9.29) \\
4.11(2.64-6.87) \\
7.76(4.77-12.62) \\
9.03(4.46-18.27)\end{array}$ \\
\hline $\begin{array}{l}\text { Thomas et al. } \\
\text { (127) }\end{array}$ & $\begin{array}{l}\text { Betel quid chewing } \\
\text { (not containing } \\
\text { tobacco) }\end{array}$ & $\begin{array}{l}\text { Oral and pharyngeal } \\
\text { cancer }\end{array}$ & 11 & - & $3.50(2.16-5.65)$ \\
\hline Pavia et al. (92) & $\begin{array}{c}\text { Fruit and vegetable } \\
\text { intake }\end{array}$ & $\begin{array}{c}\text { Oral and pharyngeal } \\
\text { cancer }\end{array}$ & 15 & 1 & $0.50(0.38,0.65)$ \\
\hline Negri et al. (87) & $\begin{array}{l}\text { Family history } \\
\text { First-degree } \\
\text { relatives } \\
\text { Siblings }\end{array}$ & $\begin{array}{l}\text { Head and neck } \\
\text { cancer }\end{array}$ & 12 & & $\begin{array}{l}1.7(1.2-2.3) \\
2.2(1.6-3.1)\end{array}$ \\
\hline $\begin{array}{l}\text { Syrjänen et al. } \\
\text { (124) }\end{array}$ & $\begin{array}{c}\text { Human papilloma- } \\
\text { viruses }\end{array}$ & $\begin{array}{c}\text { Oral and pharyngeal } \\
\text { cancer } \\
\text { OPMD }\end{array}$ & $\begin{array}{l}\text { NA } \\
\text { NA }\end{array}$ & & $\begin{array}{c}3.98(2.62-6.02) \\
4.1(2.3-7.7)\end{array}$ \\
\hline $\begin{array}{l}\text { Thomas et al. } \\
\text { (128) }\end{array}$ & $\begin{array}{c}\text { Betel quid (not } \\
\text { containing tobacco) }\end{array}$ & Oral leukoplakia & 6 & - & $7.9(4.3-14.6)$ \\
\hline
\end{tabular}

NA, not available.

countries. Meta-analysis of 10 previous studies indicates that betel quid chewing without tobacco, adjusted for smoking, has an odds ratio of 3.5 (95\% confidence interval 2.16-5.65) (Table 3) (127).

\section{Betel leaf}

The leaves of the Piper betel vine (a member of the pepper family) contain betel oil, a volatile liquid, that contains several phenols, including chavicol, hydroxychavicol, eugenol and betel phenol. These compounds may to some extent be protective, sharing some of the antioxidant properties of many plant polyphenols. Vitamin C, a large amount of carotene and 36 trace elements have also been reported in betel leaf - clearly beneficial micronutrients (145).
However the presence of such micronutrients does not justify we (or mastication) of these substances.

\section{Betel inflorescence}

Apart from leaf, other parts of the vine such as the stem, inflorescence (flowers or pods) or catkins are consumed with areca nut in some cultures. Use of the inflorescence is common in Melanesia and parts of Taiwan and mainland China, because of its aromatic flavour (51). In Papua New Guinea, this is called 'mustard'. Betel inflorescences contain a high concentration of phenolic compounds, including hydroxychavicol, eugenol, isoeugenol, eugenol methyl ester and safrole. Safrole is classified as a weak carcinogen in rats, and is banned as a food and 
cosmetic additive by the Food and Drug Administration in the USA. However, there is no direct evidence for its carcinogenicity in man.

\section{Areca nut}

Areca nut is the seed of the fruit of the oriental palm Areca catechu. Consumption is common in India, Sri Lanka, Bangladesh, Myanmar, Taiwan and numerous islands in the south-western Pacific, especially Melanesia. It is also popular in parts of Thailand, Indonesia, Malaysia, Cambodia, Vietnam, Philippines, Laos and China, and in emigrant communities from these countries. The tree may be native to Sri Lanka, west Malaysia and Melanesia. It is used as a masticatory substance by approximately 600 million people worldwide, an estimated $10-20 \%$ of the world's population (51).

The major constituents of the nut are carbohydrates, fat, proteins, fibre, polyphenols (flavonols and tannins), alkaloids and minerals. The nuts contain at least six related alkaloids, of which four (arecoline, arecaidine, guvacine and guacoline) have been well characterized (67).

Nitrosamines are produced by nitrosation of the alkaloids in dried stored nuts, when in the mouth, and especially in the acid conditions of the stomach, in the presence of nitric oxide generated by bacteria. Two of these derivatives have been found to be carcinogenic in animal studies (51), especially methylnitrosaminoproprionitrile. Endogenous nitrosation is significantly higher in subjects with poor oral hygiene as determined by volumes of dental plaque (83). On the basis of the availability of substrates from both areca nut and tobacco, there is more extensive formation of nitrosamine in subjects with poor oral hygiene if they also chew tobacco (13). Moreover, generation of reactive oxygen species, such as the hydroxyl radical (HO), in the oral cavity by auto-oxidation of polyphenols contained in areca nut (a process enhanced by the alkaline $\mathrm{pH}$ provided by the slaked lime) has been reported $(51,84)$.

\section{Areca nut-based industrial packaged products}

A variety of packaged areca products are now available. These are mostly manufactured in India and Pakistan, and exported worldwide where they are used by existing areca nut habitués and by a new generation of users. The most common are gutka and pan masala. Gutka is a dry, relatively non-perishable preparation containing areca nut, slaked lime, catechu, condiments and powdered tobacco. The same mixture without tobacco is called pan masala (39).

\section{Slaked lime}

Slaked lime (calcium hydroxide) is added to betel quids in most of South Asia. In coastal areas of Sri Lanka and islands of the Pacific, it is obtained by heating sea shells or harvested from corals. In inland areas, it is quarried from limestone. When added to betel quids, it causes erosion of oral mucous membranes, facilitating penetration of betel quid carcinogens through the mucosa.

\section{Smokeless or chewing tobacco}

Tobacco is often added to the quid mixture. Edible tobacco in the Indian sub-continent is prepared from sun-dried, partly fermented coarsely cut leaves of Nicotiana rustica and Nicotiana tabacum without further processing. Chewing tobacco results in local exposure of oral mucosa to at least 16 carcinogens, including tobacco-specific nitrosamines and polycyclic aromatic hydrocarbons (94). Unusually high levels of carcinogenic tobacco-specific nitrosamines [e.g. $N$-nitrosonornicotine (NNN) and 4-(methylnitrosamino)-1-(3-pyridyl)-1-butanone (NNK)] were reported in the saliva of oral snuff users in the Sudan (47) and tobacco chewers in India (82). NNK is a potent carcinogen, and human buccal epithelial cells (in culture) are able to metabolize NNK: the formation of macromolecular DNA adducts following NNK metabolism is correlated with carcinogenesis in animal models (139).

Chewing of betel quid releases large amounts of reactive oxygen species, especially whilst the quid is actually present. Both tobacco-specific nitrosamines and reactive oxygen species are major genotoxic agents involved in oral cancer associated with use of chewing tobacco (51). Clear dose-response relationships between quid use and the risk of oral cancer or potentially malignant oral disorders have been demonstrated in many epidemiological studies.

Most forms of oral smokeless tobacco, e.g. 'snus' (as consumed in Scandinavia) and oral snuff in North America, are not flue-cured, and contain relatively low amounts of tobacco-specific nitrosamines. Although controversial, many of these products are not highly carcinogenic, and it has been suggested that they could have a role as nicotine replacement products, assisting in achieving smoking cessation (35). However, it is important to remember that there 
is no such thing as safe tobacco: most smokeless tobaccos have high levels of nicotine and are addictive, and there is evidence that they can be initiators of smoking (40). Further, they have significant cardiovascular effects (17), and produce oral mucosal lesions and local damage to the periodontium (55).

\section{Contaminants}

Areca nut may be contaminated with fungi such as Aspergillus flavus, Aspergillus niger and Rhizopus spp. Almost $40 \%$ of samples of areca nut from India analysed using thin-layer chromatography contained aflatoxins (49). These are established carcinogens.

\section{Tobacco smoking}

Tobacco has been identified as the leading preventable cause of premature death worldwide. It is estimated that 4.9 million people died of tobacco-related illness in 2000, and it is thought that this figure will increase to 10 million deaths per year by 2020 , of which $70 \%$ will be in developing countries (139). Tobacco is a major independent risk factor for development of oral and pharyngeal cancer and other malignancies of the upper aero-digestive tract. Tobacco is consumed in various ways: cigarettes, cigars, hookah, beedi, reverse smoking and as smokeless tobacco such as loose dry oral snuff or moist snuff packed in small pouches. Tobacco smoke contains more than 60 carcinogenic combustion products. In particular, NNK, NNN and polycyclic aromatic hydrocarbons have been causally linked to upper aero-digestive tract cancer. The activity of carcinogens is generally exerted through DNA adducts $(42,50)$. Tobacco smoking and quid chewing both cause oxidative stress to tissues, i.e. the sustained presence of reactive oxygen species, which initiate free radical reactions. Reactive oxygen species can damage proteins, lipids, carbohydrates and DNA. Minor DNA damage may result in mutations that may be part of the causal chain for malignant transformation, while sustained DNA damage may result in further perturbations of cell-cycle control (146).

In addition to extensive literature on the carcinogenicity of tobacco smoke in cell and animal models, numerous case-control and cohort studies have confirmed its key role in human cancer, and the super-multiplicative synergism with alcohol drinking (115). A well-controlled meta-analysis has determined the relative risk for oral cancer in current smokers to be $3.43 \quad(95 \%$ confidence interval
2.37-4.94), and this risk is strongly dose-dependent (Table 3) (31).

\section{Alcohol}

Consumption of alcohol, including so-called 'binge drinking', is a major public health problem worldwide. Almost 2 billion adults consume alcoholic beverages regularly, with an average daily consumption of $13 \mathrm{~g}$ ethanol (between one and two drinks per day) (114). Ethanol and water are the main components of most alcoholic beverages, which also contain volatile and non-volatile flavour compounds. The major alcohol-metabolizing enzymes are alcohol dehydrogenase, which oxidizes ethanol to acetaldehyde, and aldehyde dehydrogenase, which detoxifies acetaldehyde to acetate. Acetaldehyde is responsible for the oral carcinogenic effect of ethanol, due to its multiple mutagenic effects on DNA. Specific alcoholic beverages have been shown to contain impurities or contaminants that can also be carcinogenic. $N$-nitrosodiethylamine is present in some beer and whisky, and is associated with an increased risk of oral cancer $(89,114)$. Polycyclic aromatic hydrocarbons, some of which are considered to be carcinogenic, are found in many brands of whisky $(89,114)$.

Alcohol also acts in the following ways to promote oncogenesis (89). Ethanol damages the phospholipids of cell membranes and increases permeability. It has been shown to enhance the penetration of tobacco-specific carcinogens across the oral mucosa (46). It also impairs DNA repair mechanisms, and acts as a solvent, allowing the carcinogens from tobacco to penetrate into tissue, possibly catalysing their activation. Alcohol is also highly calorific. It lessens the protective effect of beneficial foods such as fruits and vegetables by depressing hunger. Finally, ethanol is hepatotoxic, reducing the effectiveness of enzyme systems central to the detoxification of carcinogens, especially the gluthathione-S-transferases and cytochrome $\mathrm{P} 450$ systems.

Interpretation of epidemiological data on alcohol is complex. There are many confounders. Most people drink a variety of beverages, and accurate controlling for tobacco, diet, socio-economic status and other variables is challenging. A meta-analysis of 45 studies found strong dose-response relationships: the risk ratios were 1.29 (1.25-1.32) for consumption of $10 \mathrm{~g} /$ day, 1.85 (1.74-1.96) for consumption of $25 \mathrm{~g} /$ day, 3.24 (2.89-3.64) for consumption of $50 \mathrm{~g} /$ day, 5.42 (4.58-6.40) for consumption of $75 \mathrm{~g} /$ day, 8.61 (6.91-10.73) for consumption of $100 \mathrm{~g} /$ day, and 13.02 (9.87-17.18) for consumption of $125 \mathrm{~g} /$ day 
(Table 3) (129). In most epidemiological studies it is the most frequently consumed alcohol in the population concerned which is most strongly associated with risk of oral cancer.

\section{Mouthwashes}

There is considerable interest in the possible risks of head and neck cancer associated with use of alcohol-containing mouthwashes, leading some manufacturers to use 'alcohol-free' as a marketing tool. Epidemiological findings have not been consistent, and whether other major risk factors, including smoking, have been controlled for is not always easy to ascertain from published work (26). Some reviews have argued that daily mouthwash use may be an independent cause of cancers of the head, neck and oesophagus $(37,71)$. It is well-established that ethanol increases the permeability of the lining mucosa, allowing carcinogens to penetrate more freely. Acetaldehyde, the proximal metabolite of ethanol, can accumulate in the mouth from bacterial action, and, as explained above, is an established carcinogen. However, four case-control studies have shown non-significant, lower or similar oral cancer risks among self-reported mouthwash users compared to non-users $(141,144)$. The most recent meta-analysis did not demonstrate excess risk for oral cancer from alcohol-containing mouthwashes $(56,134)$. However, there is a plausible biological basis for risk associated with alcohol-containing mouthwashes, especially in smokers, and it is always prudent to remember that 'absence of evidence is not evidence for absence'.

\section{Diet and nutrition}

Dietary factors are estimated to account for approximately $30 \%$ of all cancers in Western countries (120). This proportion is currently thought to be approximately $20 \%$ in developing countries, and is projected to increase (143). Poor diet is a significant risk factor for all head and neck cancers $(20,21,32,33,60,66$, 68). A case-control study of laryngeal cancer in Italy and Switzerland between 1992 and 2000 revealed that a richness of both amount, and of variety, confers a decreased risk of laryngeal cancer (33).

The evidence comes from case-control and cohort studies, and from animal and in vitro experiments. Protective and unhealthy foods are well understood, and their avoidance forms the basis of health education messages in most countries. The micronutrients that confer benefits are also well understood.
Vitamin A and related carotenoids (in particular $\beta$-carotene), vitamins $C$ and $E$, and selenium appear to be particularly protective against most epithelial cancers $(111,112,117)$, and much of the effect is attributable to their antioxidant activities. Antioxidants act by reducing free radical reactions that can cause DNA mutations and changes in lipid peroxidation of cellular membranes (135). Other protective roles of micronutrients include modulation of carcinogen metabolism, maintenance of appropriate cell differentiation, inhibition of cell proliferation and oncogene expression, maintenance of immune function and inhibition of formation of endogenous carcinogens (146).

A recent meta-analysis on oral cancer, based on 15 case-control studies and one cohort study, utilized diet data from nearly 5,000 subjects. The analysis estimated that each portion of fruit or vegetables consumed per day reduced the risk of oral cancer by around 50\% (Table 3) (92). A large prospective study, published since this meta-analysis, showed a smaller significant risk reduction for oral cavity cancer of $26 \%$ for each additional serving of vegetables, but no association for fruit intake (30). Similar effects have been demonstrated for oral potentially malignant disorders: in a population-based case-control study in Japan comprising 48 cases of oral leukoplakia and 192 control subjects, serum levels of lycopene and $\beta$-carotene were significantly lower in those with leukoplakia; logistic regression showed that high levels of $\beta$-carotene were related to lower risk of oral leukoplakia (odds ratio $=0.16)(81)$.

Intervention studies are also encouraging in this respect. In a major double-blind placebo-controlled trial in Kerala, India (105), up to one third of subjects showed regression of oral leukoplakias after 12 months of supplementation with oral $\beta$-carotene. Extensive studies from the MD Anderson Cancer Centre in the USA are progressively identifying the most effective combinations of antioxidants for regression of oral potentially malignant disorders and prevention of recurrences and second primary neoplasms in head and neck cancer, although it should be recognized that these agents do not always prevent progression of oral potentially malignant disorders to overt cancer (90).

There is current interest in the protective effects of tea, especially green tea, which contains high levels of polyphenols (130). These are powerful antioxidants that are able to counteract both initiation and promotion of carcinogenesis (135). Similarly, studies are being performed using curcumin - the active antioxidant of the common culinary spice turmeric (22). 


\section{Genetic predisposition}

There is some evidence for a minor role of inherited, genetic predisposition in upper aero-digestive tract cancers, related to polymorphisms in carcinogen-metabolizing enzyme systems (125). A recent meta-analysis pooled individual-level data across 12 case-control studies including 8,967 head and neck cancer cases and 13,627 controls. After adjusting for confounding by age, sex, education, race/ethnicity, tobacco and alcohol, family history of head and neck cancer in first-degree relatives increased the risk (odds ratio $=1.7,95 \%$ confidence interval 1.2-2.3). The risk was higher when the affected relative was a sibling (odds ratio $=2.2,95 \%$ confidence interval 1.6-3.1) rather than a parent (odds ratio $=1.5,95 \%$ confidence interval 1.1-1.8), and for more distal head and neck sites (hypopharynx and larynx). The odds ratio increased to 7.2 (95\% confidence interval 5.5-9.5) among subjects with a family history who were alcohol and tobacco users. No association was observed for family history of non-tobacco-related neoplasms and the risk of head and neck cancer (odds ratio $=1.0,95 \%$ confidence interval 0.9-1.1) (87). Rare cancer syndromes can involve the head and neck, such as Cowden syndrome, caused by mutations in the tumour suppressor gene phosphatase and tensin homolog (PTEN), and dyskeratosis congenita, in which white oral lesions in young people have a risk of malignant transformation (41).

\section{Microorganisms}

Microorganisms have been implicated in the aetiology of oral leukoplakia for more than a century, beginning with the classic dorsal leukoplakia of syphilitic glossitis. Today tertiary syphilis is rare, but the fungus Candida albicans, a common oral commensal, is frequently found invading the upper epithelium in histological sections of leukoplakia, more so in the mouth than the pharynx or larynx (19), and this involvement is associated with a higher risk of malignant transformation (44). The terms 'candidal leukoplakia' and 'hyperplastic candidiasis' have been used to describe such lesions.

It is now clear that high-risk human papillomavirus genotypes, particularly human papillomaviruses 16 and 18, are important co-factors, especially in cancers of the tonsils and elsewhere in the oropharynx. The current state of knowledge is covered extensively elsewhere $(4,18)$. A meta-analysis by the Fifth World Workshop on Oral Medicine reviewed 1,121 published studies of oral lesions. The odds ratio for association with high-risk human papillomaviruses and oral cancer was $4.0(2.62-6.02)$ and that for oral potentially malignant disorders was 4.1 (2.3-7.7) (124).

The role of bacteria in the aetiology of upper aerodigestive tract cancers is currently receiving more attention (72). Endogenous production of acetaldehyde and reduction of nitrate to nitrites by oral flora is higher in drinkers with poor oral hygiene (45). Understanding the role of the oral flora is certainly important in management of the distressing mucositis that is frequently associated with cancer therapy.

\section{Air pollution}

Part of the urban / rural difference in the incidence of head and neck cancer has been related to atmospheric pollution. For example, mean sulfur dioxide and smoke concentrations in the atmosphere were positively correlated with squamous cancer of the larynx, and, to a lesser extent, the pharynx in data collected in the West Midland region of England between 1950 and 1990 (133).

Indoor air pollution resulting from the use of solid fuels such as wood, crop residue, animal dung and coal for cooking and heating is a significant health problem in many developing countries, where a greater proportion of people use such fuels, frequently in poorly ventilated areas. Many studies have identified indoor air pollution as a risk factor for head and neck cancer $(24,106)$, and a recent monograph by the International Agency for Research on Cancer has identified indoor air pollution from burning coal as a known human carcinogen, with that from other biomass (primarily wood) being identified as probable human carcinogens (52). Studies in China and Brazil have reported exposure to wood smoke as a risk factor for oral cancer (29), nasopharyngeal cancer (148) and cancer of the upper aero-digestive tract (96).

\section{Solar radiation}

Prolonged exposure to sunlight represents an important risk for the development of squamous cell carcinoma of the lip in people with fair complexions and those with outdoor occupations. Usually the lower lip is involved because it receives more direct sunlight (9). Such evidence comes from many countries, including those at high latitudes with clean air through which ultraviolet light penetrates easily, such as Finland (98) or Sweden (140), and from countries 
closer to the equator with regular long hours of sunshine such as rural Greece, where lip cancer accounts for $60 \%$ of oral cancers (6), and in India, for example in fishermen (104), although some protection may exist in darker-skinned races or individuals. In Finland, the increased risk for lip cancer is confounded by smoking and social class whereas that for oral cavity and pharynx is not; at these latter sites, alcohol was a much stronger contributor than tobacco (99). A study from California shows that the risk for women is strongly related to lifetime solar radiation exposure, but lipstick and other sunscreens are protective (97). There is some concern that modern cosmetic lip glosses may enhance UV damage to the lips, including increased risk of cancer (97). Decreases in the incidence of lip cancer have been interpreted as being due to reduced occupational exposure to sunlight and reduced pipe and cigar smoking $(1,58)$.

\section{Concluding remarks}

\section{References}

1. Alho OP, Keranen MR, Kantola S, Riihimaki S, Jokinen K, Alho P, Nuutinen J. Lip cancer in Northern Finland: changing incidence and clinical characteristics. J Oral Pathol Med 2000: 29: 299-302.

2. Altekruse SF, Kosary CL, Krapcho M, Neyman N, Aminou R, Waldron W, Ruhl J, Howlader N, Tatalovich Z, Cho H, Mariotto A, Eisner MP, Lewis DR, Cronin K, Chen HS, Feuer EJ, Stinchcomb DG, Edwards BK, editors. SEER cancer statistics review, 1975-2007 [WWW document]. Available at: http://seer.cancer.gov/csr/1975_2007/ [accessed on 23 March 2011].

3. Amarasinghe AAHK, Usgodaarachchi US, Johnson NW, Lalloo R, Warnakulasuriya S. Betel-quid chewing with or without tobacco is a major risk factor for oral potentially malignant disorders in Sri Lanka: a case-control study. Oral Oncol 2010: 46: 279-301.

4. Andrews E, Seaman WT, Webster-Cyriaque J. Oropharyngeal carcinoma in non-smokers and non-drinkers: a role for HPV. Oral Oncol 2009: 45: 486-491.

5. Annertz K, Anderson H, Biorklund A, Moller T, Kantola S, Mork J, Olsen JH, Wennerberg J. Incidence and survival of squamous cell carcinoma of the tongue in Scandinavia, with special reference to young adults. Int J Cancer 2002: 101: 95-99.

6. Antoniades DZ, Styanidis K, Papanayotou P, Trigonidis G. Squamous cell carcinoma of the lips in a northern Greek population. Evaluation of prognostic factors on 5-year survival rate - I. Eur J Cancer B Oral Oncol 1995: 31B: 333-339.

7. Axell T. Occurrence of leukoplakia and some other oral white lesions among 20,333 adult Swedish people. Community Dent Oral Epidemiol 1987: 15: 46-51.
8. Axell T, Rundquist L. Oral lichen planus - a demographic study. Community Dent Oral Epidemiol 1987: 15: 52-56.

9. Baker SR, Krause CJ. Carcinoma of the lip. Laryngoscope 1980: 90: 19-27.

10. Banoczy J, Rigo O. Prevalence study of oral precancerous lesions within a complex screening system in Hungary. Community Dent Oral Epidemiol 1991: 19: 265-267.

11. Bosetti C, Bertuccio P, Levi F, Lucchini F, Negri E, La Vecchia C. Cancer mortality in the European Union, 19702003, with a joinpoint analysis. Ann Oncol 2008: 19: 631640.

12. Brandizzi D, Chuchurru JA, Lanfranchi HE, Cabrini RL. Analysis of the epidemiological features of oral cancer in the city of Buenos Aires. Acta Odontol Latinoam 2005: 18: $31-35$.

13. Carossa S, Pera P, Doglio P, Lombardo S, Colagrande P, Brussino L, Rolla G, Bucca C. Oral nitric oxide during plaque deposition. Eur J Clin Invest 2001: 31: 876-879.

14. Chhetri DK, Rawnsley JD, Calcaterra TC. Carcinoma of the buccal mucosa. Otolaryngol Head Neck Surg 2000: 123: 566-571.

15. Chung CH, Yang YH, Wang TY, Shieh TY, Warnakulasuriya S. Oral precancerous disorders associated with areca quid chewing, smoking, and alcohol drinking in southern Taiwan. J Oral Pathol Med 2005: 34: 460-466.

16. Conway DI, Stockton DL, Warnakulasuriya KA, Ogden G, Macpherson LM. Incidence of oral and oropharyngeal cancer in United Kingdom (1990-1999) - recent trends and regional variation. Oral Oncol 2006: 42: 586-592.

17. Critchley JA, Unal B. Health effects associated with smokeless tobacco: a systematic review. Thorax 2003: 58: 435-443.

18. D'Souza G, Kreimer AR, Viscidi R, Pawlita M, Fakhry C, Koch WM, Westra WH, Gillison ML. Case-control study of human papillomavirus and oropharyngeal cancer. $N$ Engl J Med 2007: 356: 1944-1956.

19. De Pasquale K, Sataloff RT. Candida of the larynx. Ear Nose Throat J 2003: 82: 419.

20. De Stefani E, Boffetta P, Ronco AL, Correa P, Oreggia F, Deneo-Pellegrini H, Mendilaharsu M, Leiva J. Dietary patterns and risk of cancer of the oral cavity and pharynx in Uruguay. Nutr Cancer 2005: 51: 132-139.

21. De Stefani E, Oreggia F, Boffetta P, Deneo-Pellegrini H, Ronco A, Mendilaharsu M. Tomatoes, tomato-rich foods, lycopene and cancer of the upper aerodigestive tract: a case-control in Uruguay. Oral Oncol 2000: 36: 47-53.

22. Deng YT, Chen HM, Cheng SJ, Chiang CP, Kuo MY. Arecoline-stimulated connective tissue growth factor production in human buccal mucosal fibroblasts: modulation by curcumin. Oral Oncol 2009: 45: e99-e105.

23. Diaz EM Jr, Holsinger FC, Zuniga ER, Roberts DB, Sorensen DM. Squamous cell carcinoma of the buccal mucosa: one institution's experience with 119 previously untreated patients. Head Neck 2003: 25: 267-273.

24. Dietz A, Senneweld E, Maier H. Indoor air pollution by emissions of fossil fuel single stoves: possibly a hitherto underrated risk factor in the development of carcinomas in the head and neck. Otolaryngol Head Neck Surg 1995: 112: 308-315.

25. Elango JK, Gangadharan P, Sumithra S, Kuriakose MA. Trends of head and neck cancers in urban and rural India. Asian Pac J Cancer Prev 2006: 7: 108-112. 
26. Elmore JG, Horwitz RI. Oral cancer and mouthwash use: evaluation of the epidemiologic evidence. Otolaryngol Head Neck Surg 1995: 113: 253-261.

27. Ferlay J, Shin HR, Bray F, Forman D, Mathers C, Parkin DM. GLOBOCAN 2008: Cancer incidence and mortality worldwide. [WWW document]. Available at: http:// globocan.iarc.fr [accessed on 23 March 2011].

28. Ferlay J, Parkin DM, Steliarova-Foucher E. Estimates of cancer incidence and mortality in Europe in 2008. Eur J Cancer 2010: 46: 765-781.

29. Franco EL, Kowalski LP, Oliveira BV, Curado MP, Pereira RN, Silva ME, Fava AS, Torloni H. Risk factors for oral cancer in Brazil: a case-control study. Int J Cancer 1989: 43: 992-1000.

30. Freedman ND, Park Y, Subar AF, Hollenbeck AR, Leitzmann MF, Schatzkin A, Abnet CC. Fruit and vegetable intake and head and neck cancer risk in a large United States prospective cohort study. Int J Cancer 2008: 122: 2330-2336.

31. Gandini S, Botteri E, Iodice S, Boniol M, Lowenfels AB, Maisonneuve P, Boyle P. Tobacco smoking and cancer: a meta-analysis. Int J Cancer 2008: 122: 155-164.

32. Garavello W, Lucenteforte E, Bosetti C, La Vecchia C. The role of foods and nutrients on oral and pharyngeal cancer risk. Minerva Stomatol 2009: 58: 25-34.

33. Garavello W, Lucenteforte E, Bosetti C, Talamini R, Levi F, Tavani A, Franceschi S, Negri E, La Vecchia C. Diet diversity and the risk of laryngeal cancer: a case-control study from Italy and Switzerland. Oral Oncol 2009: 45: 85-89.

34. Garcia-Pola Vallejo MJ, Martinez Diaz-Canel AI, Garcia Martin JM, Gonzalez Garcia M. Risk factors for oral soft tissue lesions in an adult Spanish population. Community Dent Oral Epidemiol 2002: 30: 277-285.

35. Gartner C, Hall W. The potential role of snus in tobacco harm reduction. Addiction 2009: 104: 1586-1587.

36. Gourin CG, Podolsky RH. Racial disparities in patients with head and neck squamous cell carcinoma. Laryngoscope 2006: 116: 1093-1106.

37. Guha N, Boffetta P, Wunsch Filho V, Eluf Neto J, Shangina O, Zaridze D, Curado MP, Koifman S, Matos E, Menezes A, Szeszenia-Dabrowska N, Fernandez L, Mates D, Daudt AW, Lissowska J, Dikshit R, Brennan P. Oral health and risk of squamous cell carcinoma of the head and neck and esophagus: results of two multicentric case-control studies. Am J Epidemiol 2007: 166: 1159-1173.

38. Gupta PC, Nandakumar A. Oral cancer scene in India. Oral Dis 1999: 5: 1-2.

39. Gupta PC, Warnakulasuriya S. Global epidemiology of areca nut usage. Addict Biol 2002: 7: 77-83.

40. Haddock CK, Weg MV, DeBon M, Klesges RC, Talcott GW, Lando $\mathrm{H}$, Peterson A. Evidence that smokeless tobacco use is a gateway for smoking initiation in young adult males. Prev Med 2001: 32: 262-267.

41. Handley TP, McCaul JA, Ogden GR. Dyskeratosis congenita. Oral Oncol 2006: 42: 331-336.

42. Hecht SS. Tobacco carcinogens, their biomarkers and tobacco-induced cancer. Nat Rev Cancer 2003: 3: 733-744.

43. Hirota SK, Braga FP, Penha SS, Sugaya NN, Migliari DA. Risk factors for oral squamous cell carcinoma in young and older Brazilian patients: a comparative analysis. Med Oral Patol Oral Cir Bucal 2008: 13: E227-E231.

44. Holmstrup P, Vedtofte P, Reibel J, Stoltze K. Long-term treatment outcome of oral premalignant lesions. Oral Oncol 2006: 42: 461-474.
45. Homann N, Tillonen J, Rintamaki H, Salaspuro M, Lindqvist C, Meurman JH. Poor dental status increases acetaldehyde production from ethanol in saliva: a possible link to increased oral cancer risk among heavy drinkers. Oral Oncol 2001: 37: 153-158.

46. Howie NM, Trigkas TK, Cruchley AT, Wertz PW, Squier CA, Williams DM. Short-term exposure to alcohol increases the permeability of human oral mucosa. Oral Dis 2001: 7: 349-354.

47. Idris AM, Nair J, Friesen M, Ohshima H, Brouet I, Faustman EM, Bartsch H. Carcinogenic tobacco-specific nitrosamines are present at unusually high levels in the saliva of oral snuff users in Sudan. Carcinogenesis 1992: 13: 1001-1005.

48. Ikeda N, Ishii T, Iida S, Kawai T. Epidemiological study of oral leukoplakia based on mass screening for oral mucosal diseases in a selected Japanese population. Community Dent Oral Epidemiol 1991: 19: 160-163.

49. International Agency on Research on Cancer. IARC Monographs on the Evaluation of Carcinogenic Risks to Humans, Volume 82: Some Traditional Herbal Medicines, Some Mycotoxins, Naphthalene and Styrene. Lyon, France: IARC Press, 2002: 171-174.

50. International Agency for Research on Cancer. IARC Monographs on the Evaluation of Carcinogenic Risks to Humans, Volume 83: Tobacco Smoke and Involuntary Smoking. Lyon, France: IARC Press, 2004.

51. International Agency on Research on Cancer. IARC Monographs on the Evaluation of Carcinogenic Risks to Humans, Volume 85: Betel-Quid and Areca-Nut Chewing and some Areca-Nut Related Nitrosamines. Lyon, France: IARC Press, 2004.

52. International Agency for Research on Cancer. IARC Monographs on the Evaluation of Carcinogenic Risks to Humans, Volume 95: Household Use of Solid Fuels and High-temperature Frying. Lyon, France: IARC Press, 2010.

53. Iyer SG, Pradhan SA, Pai PS, Patil S. Surgical treatment outcomes of localized squamous carcinoma of buccal mucosa. Head Neck 2004: 26: 897-902.

54. Jemal A, Siegel R, Ward E, Hao Y, Xu J, Murray T, Thun MJ. Cancer statistics, 2008. CA Cancer J Clin 2008: 58: 71-96.

55. Kallischnigg G, Weitkunat R, Lee PN. Systematic review of the relation between smokeless tobacco and nonneoplastic oral diseases in Europe and the United States. BMC Oral Health 2008: 8: 13.

56. La Vecchia C. Mouthwash and oral cancer risk: an update. Oral Oncol 2009: 45: 198-200.

57. La Vecchia C, Lucchini F, Negri E, Levi F. Trends in oral cancer mortality in Europe. Oral Oncol 2004: 40: 433-439.

58. Levi F, La Vecchia C, Te VC, Franceschi S. Trends in lip cancer incidence in Vaud, Switzerland. Br J Cancer 1993: 68: 1012-1013.

59. Levi F, Lucchini F, Negri E, Boyle P, La Vecchia C. Mortality from major cancer sites in the European Union, 1955-1998. Ann Oncol 2003: 14: 490-495.

60. Levi F, Pasche C, La Vecchia C, Lucchini F, Franceschi S, Monnier P. Food groups and risk of oral and pharyngeal cancer. Int J Cancer 1998: 77: 705-709.

61. Liao CT, Wang HM, Ng SH, Yen TC, Lee LY, Hsueh C, Wei FC, Chen IH, Kang CJ, Huang SF, Chang JT. Good tumor control and survivals of squamous cell carcinoma of 
buccal mucosa treated with radical surgery with or without neck dissection in Taiwan. Oral Oncol 2006: 42: 800-809.

62. Lin CS, Jen YM, Cheng MF, Lin YS, Su WF, Hwang JM, Chang LP, Chao HL, Liu DW, Lin HY, Shum WY. Squamous cell carcinoma of the buccal mucosa: an aggressive cancer requiring multimodality treatment. Head Neck 2006: 28: 150-157.

63. Liu L, Kumar SK, Sedghizadeh PP, Jayakar AN, Shuler CF. Oral squamous cell carcinoma incidence by subsite among diverse racial and ethnic populations in California. Oral Surg Oral Med Oral Pathol Oral Radiol Endod 2008: 105: $470-480$.

64. Llewellyn CD, Johnson NW, Warnakulasuriya KA. Risk factors for squamous cell carcinoma of the oral cavity in young people - a comprehensive literature review. Oral Oncol 2001: 37: 401-418.

65. Llewellyn CD, Johnson NW, Warnakulasuriya KA. Risk factors for oral cancer in newly diagnosed patients aged 45 years and younger: a case-control study in Southern England. J Oral Pathol Med 2004: 33: 525-532.

66. Llewellyn CD, Linklater K, Bell J, Johnson NW, Warnakulasuriya S. An analysis of risk factors for oral cancer in young people: a case-control study. Oral Oncol 2004: 40: 304-313.

67. Lord GA, Lim CK, Warnakulasuriya S, Peters TJ. Chemical and analytical aspects of areca nut. Addict Biol 2002: 7: 99-102.

68. Lucenteforte E, Garavello W, Bosetti C, La Vecchia C. Dietary factors and oral and pharyngeal cancer risk. Oral Oncol 2009: 45: 461-467.

69. Macfarlane GJ, Boyle P, Scully C. Rising mortality from cancer of the tongue in young Scottish males. Lancet 1987: Oct 17; 2(8564): 912.

70. Marur S, D'Souza G, Westra WH, Forastiere AA. HPVassociated head and neck cancer: a virus-related cancer epidemic. Lancet Oncol 2010: 11: 781-789.

71. McCullough MJ, Farash CS. The role of alcohol in oral carcinogenesis with particular reference to alcohol-containing mouthwashes. Aust Dent J 2009: 53: 302-305.

72. Meurman JH, Uittamo J. Oral micro-organisms in the etiology of cancer. Acta Odontol Scand 2008: 66: 321-326.

73. Ministry of Health of Sri Lanka. National Oral Health Survey, Sri Lanka (2002/2003), 3rd edn. Colombo, Sri Lanka: Ministry of Health, 2009.

74. Moles DR, Fedele S, Speight PM, Porter SR, dos Santos Silva I. Oral and pharyngeal cancer in South Asians and non-South Asians in relation to socioeconomic deprivation in South East England. Br J Cancer 2008: 98: 633-635.

75. Moore RJ, Doherty DA, Do KA, Chamberlain RM, Khuri FR. Racial disparity in survival of patients with squamous cell carcinoma of the oral cavity and pharynx. Ethn Health 2001: 6: 165-177.

76. Moore SR, Allister J, Roder D, Pierce AM, Wilson DF. Lip cancer in South Australia, 1977-1996. Pathology 2001: 33: 167-171.

77. Moore SR, Johnson NW, Pierce AM, Wilson DF. The epidemiology of mouth cancer: a review of global incidence. Oral Dis 2000: 6: 65-74.

78. Moore SR, Johnson NW, Pierce AM, Wilson DF. The epidemiology of tongue cancer: a review of global incidence. Oral Dis 2000: 6: 75-84.
79. Morse DE, Kerr AR. Disparities in oral and pharyngeal cancer incidence, mortality and survival among black and white Americans. J Am Dent Assoc 2006: 137: 203-212.

80. Nagao T, Ikeda N, Fukano H, Miyazaki H, Yano M, Warnakulasuriya S. Outcome following a population screening programme for oral cancer and precancer in Japan. Oral Oncol 2000: 36: 340-346.

81. Nagao T, Ikeda N, Warnakulasuriya S, Fukano H, Yuasa H, Yano M, Miyazaki H, Ito Y. Serum antioxidant micronutrients and the risk of oral leukoplakia among Japanese. Oral Oncol 2000: 36: 466-470.

82. Nair J, Ohshima H, Friesen M, Croisy A, Bhide SV, Bartsch H. Tobacco-specific and betel nut-specific $N$-nitroso compounds: occurrence in saliva and urine of betel quid chewers and formation in vitro by nitrosation of betel quid. Carcinogenesis 1985: 6: 295-303.

83. Nair J, Ohshima H, Nair UJ, Bartsch H. Endogenous formation of nitrosamines and oxidative DNA-damaging agents in tobacco users. Crit Rev Toxicol 1996: 26: 149-161.

84. Nair U, Bartsch H, Nair J. Alert for an epidemic of oral cancer due to use of the betel quid substitutes gutkha and pan masala: a review of agents and causative mechanisms. Mutagenesis 2004: 19: 251-262.

85. Napier SS, Cowan CG, Gregg TA, Stevenson M, Lamey PJ, Toner PG. Potentially malignant oral lesions in Northern Ireland: size (extent) matters. Oral Dis 2003: 9: 129-137.

86. Napier SS, Speight PM. Natural history of potentially malignant oral lesions and conditions: an overview of the literature. J Oral Pathol Med 2008: 37: 1-10.

87. Negri E, Boffetta P, Berthiller J, Castellsague X, Curado MP, Dal Maso L, Daudt AW, Fabianova E, Fernandez L, Wunsch-Filho V, Franceschi S, Hayes RB, Herrero R, Koifman S, Lazarus P, Lence JJ, Levi F, Mates D, Matos E, Menezes A, Muscat J, Eluf-Neto J, Olshan AF, Rudnai P, Shangina O, Sturgis EM, Szeszenia-Dabrowska N, Talamini R, Wei Q, Winn DM, Zaridze D, Lissowska J, Zhang ZF, Ferro G, Brennan P, La Vecchia C, Hashibe M. Family history of cancer: pooled analysis in the International Head and Neck Cancer Epidemiology Consortium. Int J Cancer 2009: 124: 394-401.

88. Nichols AC, Bhattacharyya N. Racial differences in stage and survival in head and neck squamous cell carcinoma. Laryngoscope 2007: 117: 770-775.

89. Ogden GR, Wight AJ. Aetiology of oral cancer: alcohol. $\mathrm{Br}$ J Oral Maxillofac Surg 1998: 36: 247-251.

90. Papadimitrakopoulou VA, Lee JJ, William WN Jr, Martin JW, Thomas M, Kim ES, Khuri FR, Shin DM, Feng L, Hong WK, Lippman SM. Randomized trial of 13-cis retinoic acid compared with retinyl palmitate with or without betacarotene in oral premalignancy. J Clin Oncol 2009: 27: 599-604.

91. Parkin DM, Bray F, Ferlay J, Pisani P. Global cancer statistics, 2002. CA Cancer J Clin 2005: 55: 74-108.

92. Pavia M, Pileggi C, Nobile CG, Angelillo IF. Association between fruit and vegetable consumption and oral cancer: a meta-analysis of observational studies. Am J Clin Nutr 2006: 83: 1126-1134.

93. Petti S. Pooled estimate of world leukoplakia prevalence: a systematic review. Oral Oncol 2003: 39: 770-780.

94. Petti S. Lifestyle risk factors for oral cancer. Oral Oncol 2009: 45: 340-350. 
95. Pindborg JJ, Mehta FS, Daftary DK. Incidence of oral cancer among 30,000 villagers in India in a 7-year followup study of oral precancerous lesions. Community Dent Oral Epidemiol 1975: 3: 86-88.

96. Pintos J, Franco EL, Kowalski LP, Oliveira BV, Curado MP. Use of wood stoves and risk of cancers of the upper aerodigestive tract: a case-control study. Int J Epidemiol 1998: 27: 936-940.

97. Pogoda JM, Preston-Martin S. Solar radiation, lip protection, and lip cancer risk in Los Angeles County women (California, United States). Cancer Causes Control 1996: 7: 458-463.

98. Pukkala E, Notkola V. Cancer incidence among Finnish farmers, 1979-93. Cancer Causes Control 1997: 8: 25-33.

99. Pukkala E, Soderholm AL, Lindqvist C. Cancers of the lip and oropharynx in different social and occupational groups in Finland. Eur J Cancer B Oral Oncol 1994: 30B: 209-215.

100. Reibel J. Prognosis of oral pre-malignant lesions: significance of clinical, histopathological, and molecular biological characteristics. Crit Rev Oral Biol Med 2003: 14: 47-62.

101. Reichart PA. Oral mucosal lesions in a representative cross-sectional study of aging Germans. Community Dent Oral Epidemiol 2000: 28: 390-398.

102. Reichman ME, Kelly JJ, Kosary CL, Coughlin SS, Jim MA, Lanier AP. Incidence of cancers of the oral cavity and pharynx among American Indians and Alaska Natives, 1999-2004. Cancer 2008: 5 (Suppl.): 1256-1265.

103. Robinson KL, Macfarlane GJ. Oropharyngeal cancer incidence and mortality in Scotland: are rates still increasing? Oral Oncol 2003: 39: 31-36.

104. Sankaranarayanan R. Oral cancer in India: an epidemiologic and clinical review. Oral Surg Oral Med Oral Pathol 1990: 69: 325-330.

105. Sankaranarayanan R, Mathew B, Varghese C, Sudhakaran PR, Menon V, Jayadeep A, Nair MK, Mathews C, Mahalingam TR, Balaram P, Nair PP. Chemoprevention of oral leukoplakia with vitamin A and beta carotene: an assessment. Oral Oncol 1997: 33: 231-236.

106. Sapkota A, Gajalakshmi V, Jetly DH, Roychowdhury S, Dikshit RP, Brennan P, Hashibe M, Boffetta P. Indoor air pollution from solid fuels and risk of hypopharyngeal/laryngeal and lung cancers: a multicentric case-control study from India. Int J Epidemiol 2008: 37: 321-328.

107. Satyanarayana L, Asthana S. Life time risk for development of ten major cancers in India and its trends over the years 1982 to 2000. Indian J Med Sci 2008: 62: 35-44.

108. Schantz SP, Yu GP. Head and neck cancer incidence trends in young Americans, 1973-1997, with a special analysis for tongue cancer. Arch Otolaryngol Head Neck Surg 2002: 128: 268-274.

109. Scheifele C, Reichart PA, Dietrich T. Low prevalence of oral leukoplakia in a representative sample of the US population. Oral Oncol 2003: 39: 619-625.

110. Schepman KP, van der Meij EH, Smeele LE, van der Waal I. Prevalence study of oral white lesions with special reference to a new definition of oral leucoplakia. Eur J Cancer B Oral Oncol 1996: 32B: 416-419.

111. Schwartz J, Shklar G. Regression of experimental oral carcinomas by local injection of beta-carotene and canthaxanthin. Nutr Cancer 1998: 11: 35-40.
112. Schwartz JL, Shklar G, Flynn E, Trickler D. The administration of beta carotene to prevent and regress oral carcinoma in the hamster cheek pouch and the associated enhancement of the immune response. Adv Exp Med Biol 1990: 262: 77-93.

113. Scully C, Bedi R. Ethnicity and oral cancer. Lancet Oncol 2000: 1: $37-42$.

114. Secretan B, Straif K, Baan R, Grosse Y, El Ghissassi F, Bouvard V, Benbrahim-Tallaa L, Guha N, Freeman C, Galichet L, Cogliano V. A review of human carcinogens part E: tobacco, areca nut, alcohol, coal smoke, and salted fish. Lancet Oncol 2009: 10: 1033-1034.

115. Shah JP, Johnson NW, Batsakis JG. Oral Cancer. London: Martin Dunitz, 2003.

116. Shiboski CH, Schmidt BL, Jordan RC. Tongue and tonsil carcinoma: increasing trends in the U.S. population ages 20-44 years. Cancer 2005: 103: 1843-1849.

117. Shklar G, Schwartz JL, Trickler DP, Reid S. Prevention of experimental cancer and immunostimulation by vitamin E (immunosurveillance). J Oral Pathol Med 1990: 19: 60-64.

118. Sieczka E, Datta R, Singh A, Loree T, Rigual N, Orner J, Hicks W Jr. Cancer of the buccal mucosa: are margins and T-stage accurate predictors of local control? Am J Otolaryngol 2001: 22: 395-399.

119. Silverman S Jr, Gorsky M, Lozada F. Oral leukoplakia and malignant transformation. A follow-up study of 257 patients. Cancer 1984: 53: 563-568.

120. Stewart BW, Kleihues P. The causes of cancer. In: World cancer report 2003. Lyon, France: IARC Press, 2003: 22-31.

121. Suarez E, Calo WA, Hernandez EY, Diaz EC, Figueroa NR, Ortiz AP. Age-standardized incidence and mortality rates of oral and pharyngeal cancer in Puerto Rico and among Non-Hispanics Whites, Non-Hispanic Blacks, and Hispanics in the USA. BMC Cancer 2009: 9: 129.

122. Suba Z. Gender-related hormonal risk factors for oral cancer. Pathol Oncol Res 2007: 13: 195-202.

123. Sunny L, Yeole BB, Hakama M, Shiri R, Sastry PS, Mathews S, Advani SH. Oral cancers in Mumbai, India: a fifteen years perspective with respect to incidence trend and cumulative risk. Asian Pac J Cancer Prev 2004: 5: 294-300.

124. Syrjänen S, Lodi G, von Bültzingslöwen I, Aliko A, Arduino P, Campisi G, Challacombe S, Ficarra G, Flaitz C, Zhou HM, Maeda H, Miller C, Jontell M. Human papillomaviruses in oral carcinoma and oral potentially malignant disorders: a systematic review. Oral Dis 2011: 17 (Suppl. 1): $58-72$.

125. Tai J, Yang M, Ni X, Yu D, Fang J, Tan W, Huang Z, Wu C, Chen X, Wang G, Zhou W, Zhang W, Ma L, Lin D, Han D. Genetic polymorphisms in cytochrome $\mathrm{P} 450$ genes are associated with an increased risk of squamous cell carcinoma of the larynx and hypopharynx in a Chinese population. Cancer Genet Cytogenet 2010: 196: 76-82.

126. Tanaka S, Sobue T. Comparison of oral and pharyngeal cancer mortality in five countries: France, Italy, Japan, UK and USA from the WHO Mortality Database (1960-2000). Jpn J Clin Oncol 2005: 35: 488-491.

127. Thomas SJ, Bain CJ, Battistutta D, Ness AR, Paissat D, Maclennan R. Betel quid not containing tobacco and oral cancer: a report on a case-control study in Papua New Guinea and a meta-analysis of current evidence. Int $J$ Cancer 2007: 120: 1318-1323. 
128. Thomas SJ, Harris R, Ness AR, Taulo J, Maclennan R, Howes N, Bain CJ. Betel quid not containing tobacco and oral leukoplakia: a report on a cross-sectional study in Papua New Guinea and a meta-analysis of current evidence. Int J Cancer 2008: 123: 1871-1876.

129. Tramacere I, Negri E, Bagnardi V, Garavello W, Rota M, Scotti L, Islami F, Corrao G, Boffetta P, La Vecchia C. A meta-analysis of alcohol drinking and oral and pharyngeal cancers. Part 1: overall results and dose-risk relation. Oral Oncol 2010: 46: 497-503.

130. Tsao AS, Liu D, Martin J, Tang XM, Lee JJ, El-Naggar AK, Wistuba I, Culotta KS, Mao L, Gillenwater A, Sagesaka YM, Hong WK, Papadimitrakopoulou V. Phase II randomized, placebo-controlled trial of green tea extract in patients with high-risk oral premalignant lesions. Cancer Prev Res 2009: 2: 931-941.

131. Turati F, Garavello W, Tramacere I, Bagnardi V, Rota M, Scotti L, Islami F, Corrao G, Boffetta P, La Vecchia C, Negri E. A meta-analysis of alcohol drinking and oral and pharyngeal cancers. Part 2: results by subsites. Oral Oncol 2010: 46: 720-726.

132. van der Waal I. Potentially malignant disorders of the oral and oropharyngeal mucosa; terminology, classification and present concepts of management. Oral Oncol 2009: 45: $317-323$.

133. Wake M. The urban/rural divide in head and neck cancer - the effect of atmospheric pollution. Clin Otolaryngol Allied Sci 1993: 18: 298-302.

134. Warnakulasuriya S. Causes of oral cancer - an appraisal of controversies. Br Dent J 2009: 207: 471-475.

135. Warnakulasuriya S. Food, nutrition and oral cancer. In: Wilson M, editor. Food constituents and oral health: current status and future prospects. Oxford: Woodhead Publishing Limited, 2009: 273-295.

136. Warnakulasuriya S. Global epidemiology of oral and oropharyngeal cancer. Oral Oncol 2009: 45: 309-316.

137. Warnakulasuriya S, Johnson NW, van der Waal I. Nomenclature and classification of potentially malignant disorders of the oral mucosa. J Oral Pathol Med 2007: 36: 575-580.

138. Warnakulasuriya S, Mak V, Moller H. Oral cancer survival in young people in South East England. Oral Oncol 2007: 43: 982-986.

139. Warnakulasuriya S, Sutherland G, Scully C. Tobacco, oral cancer, and treatment of dependence. Oral Oncol 2005: 41: $244-260$.

140. Wiklund K, Dich J. Cancer risks among male farmers in Sweden. Eur J Cancer Prev 1995: 4: 81-90.

141. Winn DM, Diehl SR, Brown LM, Harty LC, Bravo-Otero E, Fraumeni JF Jr, Kleinman DV, Hayes RB. Mouthwash in the etiology of oral cancer in Puerto Rico. Cancer Causes Control 2001: 12: 419-429.

142. World Health Organization. Control of oral cancer in developing countries. A WHO meeting. Bull WHO 1984: 62: 817-830.

143. World Health Organization. Cancer: diet and physical activity's impact [WWW document]. Available at: http://www.who.int/dietphysicalactivity/publications/en/ [Accessed on 2 February 2010].

144. Young TB, Ford CN, Brandenburg JH. An epidemiologic study of oral cancer in a statewide network. Am J Otolaryngol 1986: 7: 200-208.

145. Zaidi JH, Arif M, Fatima I, Qureshi IH. Radiochemical neutron activation analysis for trace elements of basic ingredients of pan. J Radioanal Nucl Chem 2002: 253: 459-464.

146. Zain RB. Cultural and dietary risk factors of oral cancer and precancer - a brief overview. Oral Oncol 2001: 37: 205-210.

147. Zain RB, Ikeda N, Razak IA, Axell T, Majid ZA, Gupta PC, Yaacob M. A national epidemiological survey of oral mucosal lesions in Malaysia. Community Dent Oral Epidemiol 1997: 25: 377-383.

148. Zheng YM, Tuppin P, Hubert A, Jeannel D, Pan YJ, Zeng Y, de Thé G. Environmental and dietary risk factors for nasopharyngeal carcinoma: a case-control study in Zangwu County, Guangxi, China. Br J Cancer 1994: 69: 508-514. 